\title{
2A2-15 同調制御に基づく人間とロボットのインタラクション
}

\author{
Synchronization Based Control for Human-Robot Interactions
}

\author{
○正橋本稔（信州大）春日智史（富士通 S S L )
}

\author{
Minoru HASHIMOTO, Shinshu University, 3-15-1 Tokida, Ueda, Nagano \\ Tomofumi KASUGA, FUJITSU SSL
}

\begin{abstract}
In this study we propose a framework using neural oscillators for human-robot physical interaction such as "handshaking". Neural ascillators are used for synchronization and entrainment between human and robot motions. Passiveness of the interaction can be changed by adjusting strength of the synchronization. Joint torque information is taken as an input signal for the neural oscillators, and the neural oscillator generates the desired trajectory of a robot joint. This paper addresses a model structure of the neural oscillator for human-robot physical interaction. The experiments with a joint torque sensing robot arm show that a handshake between a robot and a human being is realized by the proposed method. Lastly the validity of the proposed method is examined by a psychological evaluation with a paired comparison method, and it is found that the proposed method is better than conventional impedance control in terms of "Flexible", "Natural", "Kind" and "Affinity".
\end{abstract}

Key Words : Human-Robot Interaction, Neural Oscillator, Torque Sensor, Handshaking

\section{1. 粕 論}

日本社会は 2014 年には高齢化率が $25 \%$ となり，4 人に 1 人は 65 歳以上の高齢者となる.このような高齢社会にお いて, 労働人口の減少, 要介護者の増大は樑刻な社会問 題となっている.介護支援ロボットの実現はその問題解 決のひとつの重要なアプローチとして位置付けられ，多 くの研究やプロジェクトが立ち上がっている ${ }^{[1],[2] . こ れ ら ~}$ の研究において，人間とロボットが直接物理的に相互作 用を行う身体的インタラクションにおいて, 安心感や親 近感を人間に与えられるかということが重要な課題とな っている.

人間同士のインタラクションにおいて，生体リズムが 相互に同調化して引き込む現象が重要な役割を果たして おり，添い寝のような幼児と母親の原始的インタラクシ ヨンにおいて，呼吸の引き込み現象が存在することが示 されている ${ }^{[3]}$. したがって，人間に一体感や共感を与える インタラクションのためには，この同調・引き込み現象 によりお互いのリズムを合わせることが本質的に重要で あると考えられる. そこで本研究では, 安心感や親近感 を与える人間とロボットの身体的インタラクションのた めには，身体的インタラクションにおける同調・引き込 みが本質的に重要であると考え, 相互のインタラクショ ンにより新たな場を創出させる方法を検討する. その上 で，インタラクションの目的や与えたい印象により異な るインタラクションの能動性や受動性を実現する方法と して，同調性を変更する方法を提案する. 身体的インタ ラクションの中には，相手に合わせる受動的なものや相 手を自分の動きにむりやり引き込む能動的なものがあり， これらを調整することがインタラクションの目的を達成 する上で重要である.

\section{2.人間とロボットの協調制御}

従来, 人間とロボットのインタラクションに関する多 くの研究が行なわれてきた。ここでは，物体運搬作業の 協調制御と人間と口ボットが直接接触する身体的インタ ラクションの研究について，概観してみよう.

人間とロボットの協調作業に関する研究では，人間同 士の協調運搬作業を実験的に解析し，人間の可変インピ 一ダンス特性をロボットに組み込むことで自然な作業を 実現する研究 ${ }^{[4]}$ が行なわれている．また，ロボットだけで は操ることができない物体を人間が作業の一部を担い, 力を加えて物体の方向を指定寸ることで，ロボットが物 体を移動することができるようにする研究[5]がある.

一方，人間とロボットが直接触れ合う身体的インタラ クションでは，人間の初期の動作を観測しながら，隠れ マルコフモデルを修正したものを用いてどの経路パター ンを追従しょうとしているかを早い段階で識別し，ロボ ットをその経路にしたがって制御する方法 ${ }^{[6]}$ が提案されて いる. また，ダンスパートナロボットシステムの研究 ${ }^{[7]} て ゙$ は，人間のダンスステップの推定を隠れマルコフモデル によって行ない，その推定結果に基づいてロボットを制 御する方法が取られている．また，人間がロボットの任 意の部位に力を加えたことをロボットが認識し，それに 応じて動作させる研究 ${ }^{[8]}$ も行われている. さらに，リハビ リテーション支援装置では，患者がマニピュレータをア クティブに等速で運動させる制御や，逆にマニピュレー タが患者の手首を等速で運動させる制御などを実現して いる ${ }^{[9]}$

しかしこれらの研究は, 人間とロボットのどちらか一 方がマスターであり，他方がスレーブとして設定されて おり，どちらかが相手に一方的に合わせるものである. ロボットの制御法としては，主にインピーダンス制御が

日本機械学会〔No. 05-44〕福祉工学シンポジウム 2005 講演論文集〔05. 12.8〜9, 津〕 
用いられ，適当なインピーダンスを設定することにより， マスターやスレーブの制御を実現する方法が取られてき た.このような制御法では，人間とロボットのどちらが マスターでどちらがスレーブであるかを前もって決めて おく必要があり，互いの運動の同調・引き込みによる創 出が行なわれておらず，一体感のあるインタラクション にはなっていないように思われる。

\section{3. 神経振動子を用いたロボット制御}

一方，神経振動子 ${ }^{[10],[1]}$ は，外界との同調などを考慮し た周期的な運動の生成が可能で, 近年，ロボットの歩行 [12], [13]やロボットアームの運動 ${ }^{[14]}$ ，またリズミックな運動

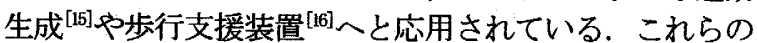
研究は, 神経振動子の有する同調·引き込み特性を利用し て，ロボットの動特性や環境変動にロバストでリズミッ クな制御を実現しようとするものである.人閒とロボッ トのインタラクションに応用された例としては, Maeda ら [17によよるロープ回しの研究がある.これは, 人間とロボ ットでロープを回す協調作業を LPL(Linear Phase-Locked Loop）という引き込み効果のあるソフトウェアを用いて実 現したものである.これは人間とロボットが直接接触し ているものではなく, 人間とロボットが直接接触する身 体的インタラクションにそのまま用いられるものではな い. また， ロボットの運動は一定の円軌道を描くものと し，その周期と位相のみを UPL を用いて引き込む方法を とっており, 複雑な運動への拡張性という点で限界があ る.さらに，同調性に関する検討は行なわれていない．

本研究では，人間とロボットの身体的インタラクショ ンにおいて, 神経振動子を用いて相互運動の同調・引き 込み現象により協調運動を創出するとともに，その同調 性を調整することによりロボットの能動性または受動性 を変更する制御法を提案し，その有用性を握手実験とそ の心理的評価実験により検証する. 人間と人間が握手を するとき，どちらかが一方的に相手に合わせるというこ とではなく，自然に同一の周期運動を作り出している. その同調の程度により，支配を意図する握手，友好的な 握手，さらに服従を意図する握手など握手の意図が異な るものと考えられている ${ }^{[18]}$. 本研究で提案する神経振動 子を用いた身体的インタラクションの制御法は, 握手の みならず，介護における患者の歩行補助やリハビリ運動 といった, 引き込みや同調を必要とする周期運動一と応 用できると考えられる.

本論文の構成は次の通りである，次章において提案す る制御法の基本構成について述べる. 次に，握手実験を 用いてその実現可能性を示すとともに, 提案手法とインピ ーダンス制御を用いた握手制御の心理評価実験を行なっ てその有用性を検討する。

\section{4. 身体的インタラクションのための同調制御}

\section{1 SBC 法}

人間とロボットの身体的インタラクションにおいて, 相互の運動を同調させるとともに，同調性を調整する制 御方法について提案する.ここでは，この同調制御法を SBC(Synchronization Based Control)法と呼ぶことにする. 本手法は, 人間と接触してインタラクションするさまざ
まなロボットに適用できるが，ここでは，ロボットアー ムを想定して説明を行なう. Fig. 1 にその基本構成を示し た.ロボットの各関節に神経振動子を設け，その出力を その関節の目標角度とする. 人間とのインタラクション によって発生する関節トルクにグインを掛けたものを神 経振動子の入力信号とする. 神経振動子の入出力間の同 調現象を利用して，人間とロボットの運動を同調させよ

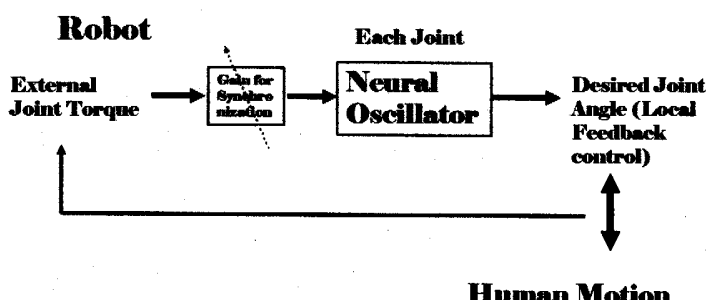

Fig 1 Block diagram of Synchronization Based Control (SBC)

うとするものである.ここで，入力ゲインを変更するこ とにより，その同調の程度を連続的に変更することがで きる.

\section{2 神経振動子の構成}

生物の歩行運動や呼吸などのリズミックな運動生成に, 神経振動子が用いられていると考えられている．神経振 動子は，入力された周期的な信号に対して同調すること により，容易に外部事象に対して同調するという機能を 有することが知られている.

神経振動子の数学モデル（松岡モデル[10], [11]) は式(1)（3）で表される非線形 1 階連立微分方程式で表せる. ま た，ユニットの構造を Fig. 2 に示す.

$$
\begin{aligned}
& T_{r} \frac{d x_{i}}{d t}+x_{i}=-\sum_{j \neq i} a_{i j} g\left(x_{j}\right)-b_{i} x_{i}^{\prime}+s_{i}+\text { Input } \\
& T_{a} \frac{d x_{i}^{\prime}}{d t}+x_{i}^{\prime}=g\left(x_{i}\right) \\
& g\left(x_{i}\right)=\max \left(0, x_{i}\right)
\end{aligned}
$$

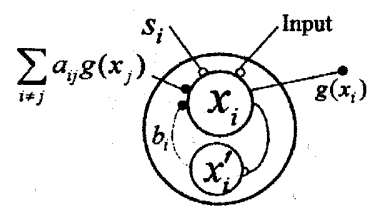

Fig. 2: Structure of unit

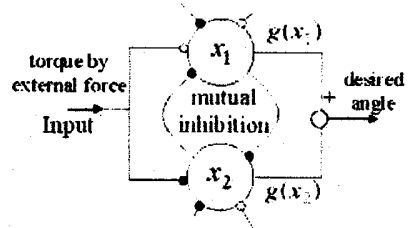

Fig 3: Mutual inhibition

\section{ここで, $x_{i}$ は $i$ 番目のニューロンの内部状態を表す変}

数, $x_{i}^{\prime}$ はニューロンの疲労状態を表す変数, $g\left(x_{i}\right)$ は二 ユーロンの出力, $S_{i}$ は定常入力, $b_{i}$ は疲労係数, $a_{i j}$ は $j$ 番目のニューロンから $i$ 番目のニューロンへの結合 係数, $T_{r}, T_{a}$ は時定数である. Input はニューロンへの 入力である.

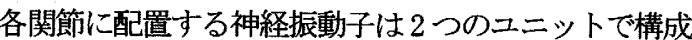
される. その構造をFig. 3 に示した. ここで, 関節 $\mathrm{i}$, ユ ニット $\mathrm{j}(\mathrm{j}=1,2)$ の神経振動子の振る舞いを，(1)-(3)式を 変形した(4)-(6)式で表す。 


$$
\begin{aligned}
T_{r} \frac{d x_{i j}}{d t}+x_{i j} & =-\sum_{k \neq j} a_{i k} g\left(x_{i k}\right)-b_{i j} x_{i j}^{\prime}+s_{i j} \\
& +(-1)^{j-1} K_{i}\left(\sum_{l \neq i}\left(g\left(x_{l 1}\right)-g\left(x_{l 2}\right)\right)\right) \\
& +(-1)^{j-1} \operatorname{Input} 1+\operatorname{Input} 2 \\
T_{a} \frac{d x_{i j}^{\prime}}{d t} & +x_{i j}^{\prime}=g\left(x_{i j}\right) \\
g\left(x_{i j}\right)= & \max \left(0, x_{i j}\right) \\
\text { Input1 } & =\mathrm{C}_{\mathrm{i}} \tau_{i} \\
\text { Input } 2 & =\mathrm{L}_{\mathrm{i}}\left|\tau_{i}\right|
\end{aligned}
$$

以下に，本制御法のために(1)-(3)式を変更して，新たに 加えられた項についての詳細を述べる.

(4)式の第 4 項は，関節間の同調と安定な振動を目的と

している. $\sum_{l \neq i} g\left(x_{l 1}\right)-g\left(x_{l 2}\right)$ は自分以外の神経振動子の

出力を加え合わせることを表している． $K_{i}$ はそれに掛

けられる定数である.

Input 1 に関する項は, 周波数の同調のためのものであ り，(7)式で表される.ここで， $\tau_{i}$ は人間との相互作用に より発生した第 $\mathrm{i}$ 関節の関節トルクである. $C_{i}$ は定数で, 入力の大きさを調整するゲインである.この入力は，2個 のユニットにそれぞれプラスとマイナスを掛けて入力す る.

Input2 は，人間の振幅に合わせるためのものであり， (8)式で表される.ここで， $L_{i}$ は調整ゲインで，関節卜 ルクの絶対値に掛けて, Input2 とする. Input1 とは異な り，各ユニットに加算する.これにより，人間が加えた 力に応じた出力 (目標角度) が得られる. また, Input2 を入力することにより，神経振動子自身の持つ周波数が わずかに変化するが，無視できる程度のものであること がわかっている.

各関節の目標角度は, 神経振動子の出力に $O_{i}$ を用いて ゲイン調整したものである.

関節数 2 の場合について，(4)-(8)式で表される神経振 動子の構造を Fig.4に示した。詳細については，文献[19] を参照されたい.

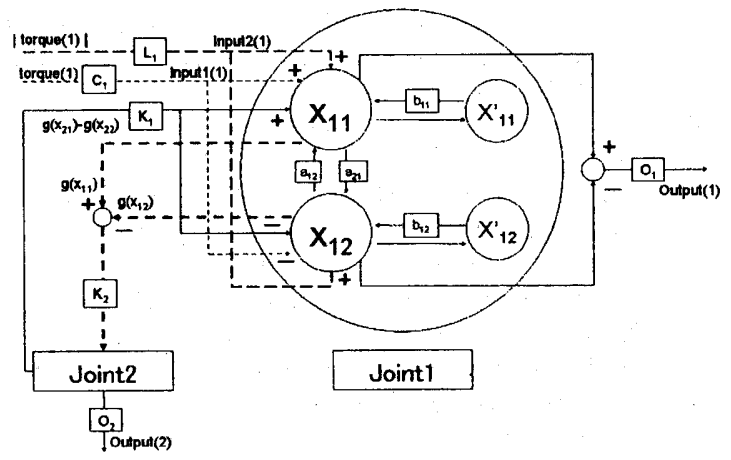

Fig 4 : Structure of the Neural Oscillator

\section{5. 握手制御実験}

実験に用いるロボットアームは関節トルクセンサ内蔵 型 7 自由度アーム[ 関節) の目標角度を, 神経振動子を用いて決定し, その 他の関節は一定の角度の位置制御をしている. 実験の様 子を Fig. 5 に示した. Input1，Input2は，関節トルクセン サの出力から重力項を除去した值を用いて算出し, 神経 振動子へフィードバックされる. 制御に用いた神経振動 子のパラメータの值は, $\mathrm{Tr}=0.086, \mathrm{Ta}=0.043, \mathrm{a}_{\mathrm{ik}}=0.8$, $\mathrm{s}_{\mathrm{ij}}=2.0, \mathrm{~b}_{\mathrm{i}}=2.5,0_{\mathrm{i}}=5.73, \mathrm{~K}_{\mathrm{i}}=1.2, \mathrm{C}_{\mathrm{i}}=0.04$ and 0.01 , $\mathrm{L}_{\mathrm{i}}=0.13$ である. この場合, インタラクションがない状態 でのロボットの基本周波数は $1.5 \mathrm{~Hz}$ となっている.

ここで人間とロボットが同調しているかを調へるため に，画像処理ボード IP7000を用いて人間の関節角の計測 を行った. $C_{\mathrm{i}}$ を調整し，柔軟に設定した場合の握手の結 果をFig. 6に, 堅固に設定した場合の握手の結果を Fig. 7 に示した.

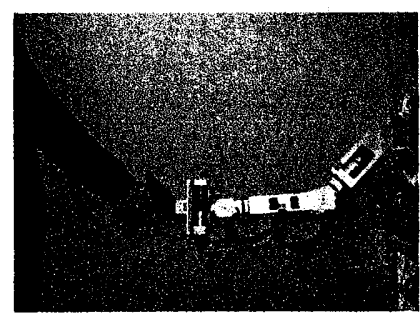

Fig 5:Overview of a human-robot handshake
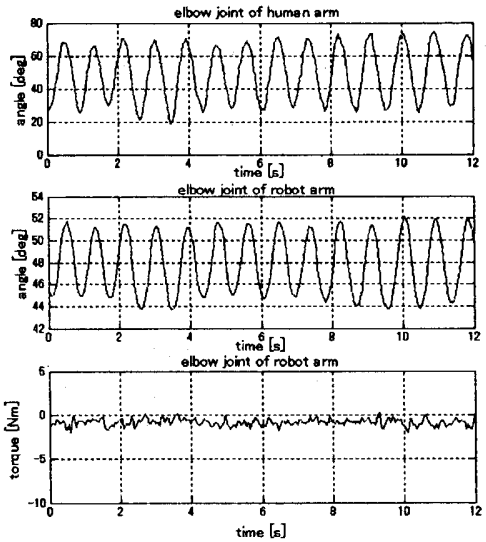

Fig.6 : Experimental results $(\mathrm{C} i=0.04)$
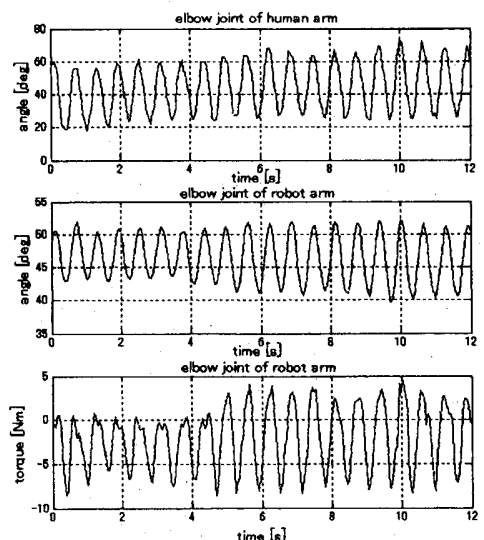

Fig. 7 : Experimental results $(\mathrm{Ci}=0.01)$ 
この結果から, Fig. 6 では, 関節トルクが小さく, 周波 数も $1.1 \mathrm{~Hz}$ 程度で, 口ボットは人間に対して受動的に振 舞っていることが分かる. 一方，Fig.7 では，大きな関節 トルクが発生しており，周波数がロボット自身の持つ基 本周波数に近い.これは，ロボットが人閒に対して能動 的に働いており，ロボット自身の運動に人間の動きをあ る程度引き込んでいるためだと考えられる. 以上より， $\mathrm{C}_{\mathrm{i}}$ の值を変えることにより, ロボットアームの同調性を変 更でき，受動的な握手，能動的な握手，またはその中間の 握手を容易に契現できることを示している.

\section{6. 心理訶価実馀}

本研究で提案した握手制御法の有效性を調べるために, 人間とロボットの握手の心理評価実験を行った. 評価方 法にはBradley の一対比較法 ${ }^{[2]}$ を用いた．神経振動子を用 いた握手を 2 種類, 従来考えられる方法であるインピー ダンス制御を用いた握手を 2 種類, 計 4 種類の試料を用 意し，そのうちの 2 つずつを組にして比較してもらい， どちらがより好ましい握手であるかを，「柔軟である」， 「自然である」，「優しい」，「親近感のある」の 4 項 目について 12 名の被験者に評価してもらった. 試料の詳 細は以下に示す．実験順や組み合わせは無作為に選んで いる. また，周波数と振幅は全ての試料で統一してある.

a 神経振動子を用いた握手（とても柔軟）

b. 神経振動子を用いた握手 (やや柔軟)

c. インピーダンス制御を用いた握手 (甽性小さめ)

d. インピーダンス制御を用いた握手 (岡性大きめ)

各資料の判定比 (尺度值) を $\pi_{a}, \pi_{b}, \pi_{c}, \pi_{d}$ とし，それ ぞれの評価項目についてそれらを推定し，さらに $\chi_{0}^{2}$ を求め ると, Tablel のようになった。 自由度 3 のカイ 2 乗分布の $5 \%$ 点は $\chi^{2} \quad(3,0.05)=7.82$ なので, 全ての評価項目で

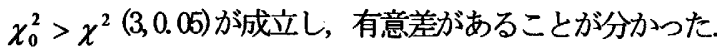

また，神経振動子を用いた場合 (a b b とインピーダンス制 御を用いた場合 $(\mathrm{c}, \mathrm{b})$ とでは，ほとんどの被験者が神経振動 子の方を良いとしていることが分かった.これは，インピー ダンス制御は周波数を相手に合わせられないなど同調の能力 がないが, 神経振動子は周波数の変化などに柔軟に対応寸る ことができるからではないかと考えられる. また，a とbを 比較すると，「柔軟である」という評価項目以外忙， b の順 位が高い:この結果は，受動的であり過ぎるよりも，ある程 度能動的である方が，人間にとって快適だということを表し ているのではないかと考えられる.

\section{7. まとめ}

人間とロボットの身体的インタラクションにおいて, お互い運動の同調が, 自然で一体感のあるインタラクシ ヨンを実現する上で，重要であることを指摘し，さらに 友好的なインタラクションなど, 特定の意図を持たせる ためにはその同調性を調整する必要があることを指摘し た. その上で，このようなロボット制御を実現するため に，神経振動子を用いた同調制御法（SBC 法）を提案し， 握手実験によりその有効性を示した. さらに，人間にと ってどのような印象を与えるかを評価するために，本制 御法と, 従来のインピーダンス制御法により握手実験を 行い, 一対比較法により心理評価を行なった，その結果， 「自然である」，「親近感のある」などの点で, 提案手 法が優れていることが分かった.
Table1 : Interval scale and $\chi_{0}^{2}$

\begin{tabular}{|c||c|c|c|c|c|}
\hline & $\pi_{a}$ & $\pi_{b}$ & $\pi_{c}$ & $\pi_{d}$ & $\chi_{0}^{2}$ \\
\hline flexible & 0.46 & 0.37 & 0.11 & 0.06 & 25.46 \\
\hline natural & 0.34 & 0.47 & 0.11 & 0.08 & 21.15 \\
\hline kindly & 0.40 & 0.45 & 0.11 & 0.04 & 31.41 \\
\hline affinity & 0.37 & 0.46 & 0.10 & 0.07 & 24.37 \\
\hline
\end{tabular}

\section{考文献}

[1] http//www.wasedajp/pij-t/

[2] 木下源一郎：“人とロボットの共生, ”第 7回日本感性工 学会大会予稿集, 69/1(2005)

[3] 渡辺富夫, 大久保雅史：“コミュニケーションにおける引 き込夕現象の生理的側面からの分析評価,”情報処理学会論 文誌, Vol 39, No.5, 1225-1230,(1998)

[4] 池浦 良淳 : “ロボットー人間協調システムのモデリング,” 日本ロボット学会誌, Vol18, №. 3, pp. 331-336, 2000.

[5] 平田泰久, 初雁卓郎, 小菅一弘, 浅間一, 嘉悦早人, 川端 邦明 : “人間と複数の分散型ロボットヘルパーとの協調に よる単一物体の搬送,” 日本機械学会論文集 (C 編)，68 巻, 668 号, 1207-1214, 2002.

[6] 山田陽慈：“人の意を考慮した人間/知能機械系”計測と制 御, Vol 38, No.6,363-368,(1999)

[7] 竹田貴博, 小菅一弘, 平田泰久: “ダンスパートナロボッ トシステム-MSDanoeR-第 5 報 : 隐れマルコフモデルを用い たダンスステップの推定と複数のユーザへの適用-, ”日本 機械学会ロボティクスメカトロニクス講演会, IP1-N-057(1)(2), (2005)

[8] Hiroyesu Iwata, Hayato Hoshino, Toshio Morita, and Shigeki Sugano : "Human Robot Physical Interaction Utilizing Force Detectable Tactile Covers." "i Proc. of the Fist IEEERA I Intemational Conference on Humanoid Robots (Humanoids 2000), paperno.87, 2000.

[9] 高岩昌弘, 則次俊郎, 正子洋二：“空気式パラレルマニピ ユレータを用いた手首部リハビリテーション支援装置の開 発，”第23回日本ロボット学会学術講演会, 1J22, (2005)

[10] Kiyotoshi Matsuoka: "Sustained Oscillations Generated by Mutually Inhibiting Neurons with adaptation,"Biological Cybemetics, 52, 367-376, 1985.

[11] Kiyotoshi Masuoka:"Mechanisms of Frequency and Pattem Control in the Neural Rhythm Generators," Biological Cybemetics, 56, 345-353, 1987.

[12] Gentaro Taga: "A model of the neuro-musculo-skeletal system for human location,"Biological Cybemetics, 73,97-111,1995.

[13] 木村浩, 秋山征一, 桜間一彰: “神経振動子を用いた四足口ボット の不整地動频行と整地走行, ”日本口ボッ学会誌, Vol.16, No.8, 1138-1145,(1998)

[14] Mathew M. Williamson: "Neural Control of Rhythmic Arm Movements" Neural Networks, 11, 1379-1394,(1998)

[15] 琴坂 信哉,Stefn Schaal:“神経振動子を用いたロボットのリスシック な運動生成,"日本口ボッ学会誌, vol 19,No.1,pp.116-123,2001

[16] 高梨豪也，三宅美博 : “共創型介助ロボット"Walk-Mate”の歩 行障害一の適用, ”計測自動制御学会論文集, vol.39,no.1,7481 (2003)

[17] Yusuke Maeda, Assushi Takaheshi, Takayuki Haraand Tamio Arai: "Human-obot Cooperative Rope Tuming-AnExample of Mechanical Coordination through Rhythm Entrainment," Advanced Robotics, Vol 17, No.1,67-78,(2003)

[18] デイビッド・ルイス: “成功のためのボディ・ランゲー ジ,”（金利光訳），東京図書，pp.129-146,(1998)

[19] 春日智史,橋本稔：“神経振動子を用いた人間とロボットの 握手一制御実験と評価一, ”日本機械学会ロボティクス・ メカトロニクス講演会, 1P2N-058(1)-(2),(2005)

[20] Minonu Hashimoto, Tomofimi Kasuga and Masashi Horiuchi: "Development of Joint Torque Sensing Robot Arm for Human-Robot Physical Interactions," in proc. of 6th Japan-France \& \& 4h Asia-Europe Mechatronics Congress, pp.163-168,(2003)

[21］日科技連官能検查委員会，“新版 官能検査ハンドブッ ク，”日科技連出版部, pp.385-393,(1973) 